\title{
Analysis Performance of Village-Owned Enterprise: Optimization of Organizational and SWOT Structures on Village-Owned Enterprise "Mitra Usaha Makmur"
}

\author{
Jaryono $^{1}$, Tohir $^{2}$, Lina Rifda Naufalin ${ }^{3}$, Aldila Krisnaresanti, ${ }^{4}$ Dwiniti Wuriasih ${ }^{5}$ \\ 1, 2, 3, 4,5) Faculty of Economics and Business, Jenderal Soedirman University, Purwokerto, Indonesia \\ 53122
}

\begin{abstract}
This study aims to analyze how the role of commissioners, managers, supervisors, and labor in determining the performance of Village-Owned Enterprise "Mitra Usaha Makmur"; and also analyze the performance of VillageOwned Enterprise "Mitra Usaha Makmur" based on the SWOT analysis. It is a qualitative descriptive study that seeks to reach conclusions through a process of in-depth study both directly and through relevant literature. With analysis techniques in the form of data reduction and SWOT. The subject in this research is Village-Owned Enterprise"Mitra Usaha Makmur", which is located in the village of Susukan Sub district Subdistrict Banyumas Regency. The results of this study are the commissioners, managers, supervisors, and workforce who have a contributory role in achieving the performance of Village-Owned enterprise "Mitra Usaha Mamkmur", they are able to separate the duties and authority of each party in the guidelines of the Statutes/Bylaws Village-Owned Enterprise "Mitra Usaha Mamkmur" and run these duties and authorities. Then the analysis performance of SWOT Village-Owned Enterprise"Mitra Usaha Makmur" is able to produce Village-Owned Enterprisefocus in developing future strategies, into internal factors and internal factors. Internal factors include the strategy of developing Human Resources (HR), Capital, and marketing strategies. While external factors include strengthening local wisdom of the implant village itself.
\end{abstract}

Keywords: Village-Owned Enterprise, Performance, Organizational Structure, SWOT

DOI: $10.7176 / \mathrm{EJBM} / 11-30-10$

Publication date:October $31^{\text {st }} 2019$

\section{Introduction}

Towards an independent village needs to be pursued by every element of the village government in the country of Indonesia. Village-Owned Enterprise as a business entity managed and owned by the village government can be optimized by Empowering Natural Resources and Human Resources (HR) to improve the welfare of its people. The existence of this Village-Owned Enterprise is supported by the government in Law No. 32 of 2004 concerning Regional Government Ayat 21 paragraph (1), namely villages can establish village-owned business entities in accordance with the needs and potential of the village. Become a forum for village economic activities. VillageOwned Enterprise has a function as a business entity that organizes social services to the community, and commercial business entities that contribute to the village. According to the Center Team for the Study of System Dynamics in the Faculty of Economics, Brawijaya University (2007), Village-Owned Enterprise is a pillar of economic activity in the village that functions as asocial institution and a commercial institution. Village-Owned Enterprise as a social institution favors the interests of the community through its contribution in the provision of social services. Meanwhile, as a commercial institution, it aims to make a profit through offering local resources (goods and services) to the market.

The attention of the village to become an independent village has now begun to grow. In the province of Central Java until 2017 the development of the number of Village-Owned Enterprise has increased, with a total VillageOwned Enterprise in 29 districts in Central Java totaling 1993 Village-Owned Enterprise, where the financial services business unit dominates the existing Village-Owned Enterprise as many as 659 Village-Owned Enterprise or 33\% of the total Village-Owned Enterprise (Dispermades Dukcapil Central Java, 2017). In the discordant subdistricts included in the administrative area of Banyumas Regency, Central Java Province, one of them is the Village-Owned Enterprise which has been categorized as Village-Owned Enterprise in the 'developing' strata by the Social Service and Community and Village Empowerment Department (2019), namely Village-Owned Enterprise "Mitra Usaha Makmur" located in Susukan village, sumbang sub-district, banyumas district. Newly established since 2015 by an initiator of the susukan village migrant community who saw the potential of natural resources and human resources in the susukan village, Village-Owned Enterprise "Mitra Usaha Makmur" is now quite prestigious and contributory to the susukan village. Starting in 2017 Village-Owned Enterprise "Mitra Usaha Makmur" is able to increase the receipt of Village Original Income (PAD) by 7.5 million rupiah, with a total up to semester I of 2019 of 56.5 million rupiah. Not only does it increase the receipt of Village Original Income (PAD), 
Village-Owned Enterprise "Mitra Usaha Makmur" is also able to provide employment for the villagers of breastfeeding.

Achievement of Village-Owned Enterprise "Business Partners Prosperous" is inseparable from good business management from stakeholders Village-Owned Enterprise (management), so as to produce a good performance Village-Owned Enterprise "Business Partners Prosperous". Good performance as a result of the work done by Village-Owned Enterprise employees "Mitra Usaha Mamkmur" involves how stakeholders delegate their authority and duties to employees in working, in line with the objectives of Village-Owned Enterprise "Mitra Usaha Mamkmur". A description of the delegation of authority, and duties by Village-Owned Enterprise (management) stakeholders can be seen how the organizational structure is implemented by Village-Owned Enterprise "Mitra Usaha Makmur". The development of the Village-Owned Enterprise "Mitra Usaha Makmur" business can also have the potential to develop even better.

Based on the background of the study, the researcher intends to conduct research on the performance analysis of Village-Owned Enterprise "Mitra Usaha Makmur" in terms of the organizational structure that is carried out, and the SWOT analysis. With this research question, namely:

Q1: What is the role of commissioners, managers, supervisors and workers in determining the performance of Village-Owned Enterprise "Mitra Usaha Makmur" Susukan Village Sumbang District Banyumas Regency?

Q2: How is the performance analysis of Village-Owned Enterprise "Mitra Usaha Makmur" Susukan Village Sumbang District Banyumas Regency based on the SWOT analysis?

This research is a type of descriptive qualitative research, namely research that describes, illustrates, compares a data and a situation and explains a situation in such a way before drawing a conclusion (Sugiyono, 2014). With data collection techniques through interview techniques, observation, study documentation, books, and other sources relevant to research. In analyzing the data that has been obtained, analyzed with interactive model analysis techniques consisting of data collection, data reduction, data presentation, data quality testing, and drawing conclusions. In addition this study also uses SWOT analysis techniques.

This research is expected to provide an overview of the performance of Village-Owned Enterprise that fall into the category of "Developing" so that it can be an example and model to be applied to other Village-Owned Enterprise. In addition, this research is expected to be able to provide input to the village's Village-Owned Enterprise based on SWOT analysis (Strength, Weakness, Opportunity, Threat) which aspects should be improved and aspects that can be developed in Village-Owned Enterprise management so that they can be better.

\section{Literature Review}

\section{Village-Owned Enterprise}

Village-Owned Enterprise is a business entity whose entire or most of its capital is owned by the Village through direct participation from village assets that are separated to manage assets, services, and other businesses for the maximum welfare of the village community (Village Government Regulation No 4 of 2015 (Ayat 1)).

Establishment of Village-Owned Enterprise is based on the potential of the village, and also the needs of the surrounding community. In Law No. 32 in 2004 of concerning Regional Government Ayat 21 paragraph (1) states that villages can establish village-owned enterprises in accordance with the needs and potential of the village. What is meant by "needs and potentials village" are: Community needs especially in meeting basic needs; There are village resources that have not been used optimally, especially village wealth and there is demand in the market; Available human resources capable of managing business entities as assets driving the community's economy; Business units that are part of the community's economic activities that are managed partially and are not accommodated;

Village-Owned Enterprise was established with the aim of: Improving the village economy; Increase village original income; Improve processing of village potential in accordance with community needs; Becomes the backbone of rural economic growth and equity (Center for Dynamics of Development Systems Development, 2007).

\subsection{Performance}

According to Murdjianto (2001) Performance is the work that can be achieved by a person or group of people in an organization in accordance with their respective authorities and responsibilities in an effort to achieve the organization's objectives legally, not breaking the law and in accordance with morals and ethics. Meanwhile, 
according to Srimindarti (2006), Performance is a periodic determination of the operational effectiveness of an organization, parts of the organization and its employees based on predetermined targets, standards and criteria. Employee performance is not just information to be able to do the promotion or determination of salary for the company, but how the company can motivate employees and develop a plan to improve the deterioration in performance so that it can be avoided.

According to Keith Davis, quoted by AA Anwar Mangkunegara (2006), employee performance can be influenced by the following factors, namely: Ability Factors; Motivation Factor; Individual Factors; Organizational Environmental Factors. According to Sutrisno (2009), performance measurement is directed at six aspects, namely:

2.1 Work results represent the level of quantity and quality that has been produced and the extent of supervision carried out,

2.2 Job knowledge is the level of knowledge associated with work tasks that will directly influence the quantity and quality of work results,

2.3 Initiative is the level of initiative during carrying out work tasks, especially in terms of handling problems that arise,

2.4 Mental ability is the level of ability and speed in accepting work instruction and adjust to the way work and work situations that exist,

2.5 Attitude is the level of morale and positive attitude in carrying out work duties,

2.6 The discipline of time and attendance is the level of timeliness and level of attendance.

\section{Organizational Structure}

According to Hasibuan (2010) organizational structure is a picture depicting the type of organization, departmental organization position, and the type of official authority, field and job relations, line of command and responsibility, span of control and organizational leadership system. And according to Robbins and Coulter (2007), organizational structure can be interpreted as a formal organizational framework within which the work tasks are divided, grouped, and coordinated.

Hall (1996) states that organizational structure has three basic functions, namely (1) Organizational structure must produce organizational output and to achieve organizational goals, (2) Organizational structure is designed to minimize or at least regulate the influence of individual variations within the organization, (3) The organizational structure must regulate which parts have power, which parts govern the policies or regulations and which parts carry out activities, because the structure is the place for the organization to work.

\section{SWOT}

According to Keller (2009), SWOT analysis (strengths, weaknesses, opportunities, threats) is an overall evaluation of strengths, weaknesses, opportunities, and threats. Strength (Strength), is the strength of the company compared to other companies; Weakness (Weakness), are the problems faced by the company compared to other companies, so this is a weakness for the company; Opportunity (Opportunity), is an opportunity where a company can conduct operations in facing challenges and to make that opportunity an advantage; Threat (Threat), is a danger that usually occurs due to unfavorable developments, which will have effects such as reduced profits and sales if no action is taken to survive.

According to Riadi (2013), the SWOT analysis has the function of obtaining information from a situation analysis and separating it into internal issues (strengths and weaknesses) and external issues (opportunities and threats). The SWOT analysis will explain whether the information has something that will help the company achieve its objectives or give an indication that there are obstacles that must be faced or minimized to meet the desired income.

\section{Result}

The role of the Village-Owned Enterprise Commissioner, manager, supervisor, and manpower of Village-Owned Enterprise "Mitra Usaha Makmur"

following is an overview of the organizational structure of Village-Owned Enterprise "Mitra Usaha Makmur": 
Picture 1. Structur Organizational of Village-Owned Enterprise "Mitra

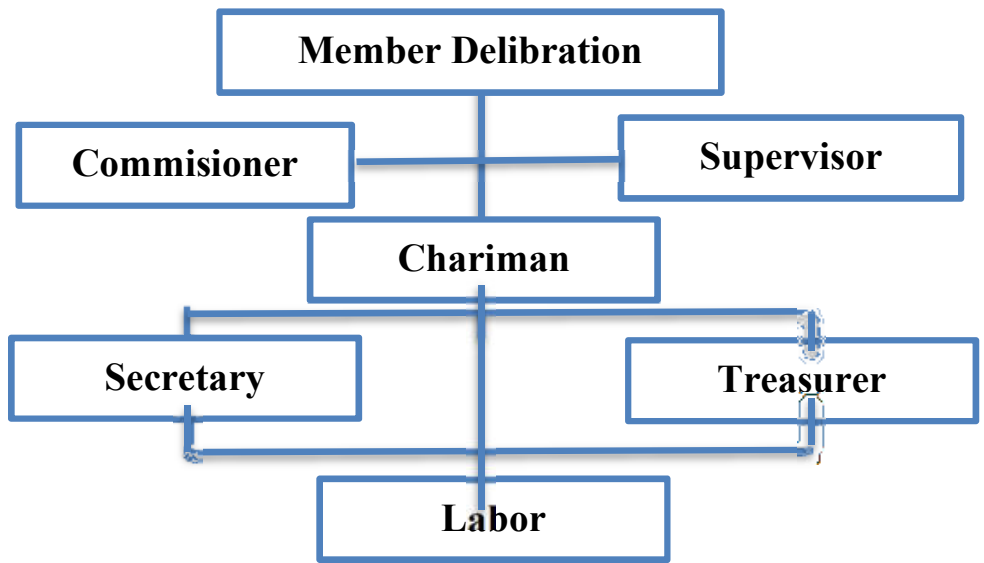

Sources : Secondary Data Processed

Based on the results of interviews and analysis STATUTES/BYLAWS documentations of Village-Owned Enterprise "Mitra Usaha Makmur", it is known how the role of commissioners, managers, supervisors, and labor as the Human Resources (HR) driving Village-Owned Enterprise "Mitra Usaha Mamkmur", the following explanation:

The Role of the Supervisors

Village-Owned Enterprise "Mitra Usaha Makmur" consists of 2 people from community leaders and representatives of the Village Consultative Body (BPD) of the Susukan Village. The supervisor plays the role of information facilitator between the Village-Owned Enterprise and the village community in the village consultation held by the Village Consultative Body (BPD). In its responsibility, the manager of the Village-Owned Enterprise "Mitra Usaha Makmur" Susukan Village, Sumbang Subdistrict, reports its activities to the supervisors and then submits them to the community and villages in the Village Conference. So that the wider community can know the performance of Village-Owned Enterprise "Mitra Usaha Makmur". This is intended because in the VillageOwned Enterprise STATUTES/BYLAWS can not directly deliver the results of its performance to the community, so it must go through procedures to the supervisors and commissioners.

The role of the Commissioner

Commissioner Village-Owned Enterprise Commissioner "Mitra Usaha Makmur" is the village head of the implant, has a role in policy making and legality. Policies in the allocation of village budgets for Village-Owned Enterprise, and licensing in every business activity proposed by Village-Owned Enterprise. This was sufficiently felt by the ease in licensing and in facilitating the commissioners given to Village-Owned Enterprise. The second role as legality, all decisions by the management must be approved by the commissioner as the holder of legality.

The role of theManager

Village-Owned Enterprise Manager "Mitra Usaha Makmur" consists of 3 people who act as chairpersons, secretaries, and treasurers. The election of manager of the Village-Owned Enterprise "Mitra Usaha Makmur" comes from the community who have an active contribution to the breastfeeding village, as well as an initiator who sees the Village-Owned Enterprise business potential now serving as chairman. Each manager has a role as regulated in the Statutes/Bylaws Village-Owned Enterprise "Prosperous Business Partners" are as follows:

\section{Chairperson,}

Head of Village-Owned Enterprise organization; Control Village-Owned Enterprise activities; Acting on behalf of the institution to hold cooperation agreements with third parties in business development or other activities deemed necessary; Report to Village-Owned Enterprise finance every month to Sektap; Report Village-Owned Enterprise financial condition every quarter through Musdes; Report the financial condition of Village-Owned Enterprise at the end of the year through the Responsibility Nudes.

Secretary,

Carry out secretarial tasks to support the chairman's activities; Carry out general administration of Village-Owned Enterprise operational activities; Carry out administration of Village-Owned Enterprise financial accounting; 
Together with the chairman, examine the validity of the files for checking loans in the field (in the case of VillageOwned Enterprise Savings and Loans); Together with the chairman and treasurer to discuss and decide on a loan application that is feasible to be realized (in the case of Village-Owned Enterprise savings and loan) and also check the correctness of savings and deposit balances (this activity can be done at any time as needed).

Treasurer,

Receives, saves and pays money based on valid evidence; Assist the chairman in discussing and deciding which loan applications are feasible to be realized (in the case of Village-Owned Enterprise Savings and Loans); Reporting the financial position to the chairman systematically, can be accounted for and addressed the actual financial condition and feasibility of Village-Owned Enterprise; Issuing money based on valid evidence; Regulate liquidity as needed; Deposit money to the Bank after obtaining approval from the Chairperson.

The Role of Workers

The Village-Owned Enterprise "Mitra Usaha Makmur" workforce as the implementer of the Village-Owned Enterprise business technique, has the role of supporting and supporting Village-Owned Enterprise "Mitra Usaha Mamkmur" Village-Owned Enterprise. Workers have a duty as a guard ticket counter visitors; Serving the needs of visitors in the utilization of Village-Owned Enterprise facilities; Maintaining the cleanliness of the VillageOwned Enterprise environment; Maintain security and order Village-Owned Enterprise.

Village-Owned Enterprise SWOT Analysis of "Business Partners Prosperous"

Village-Owned Enterprise SWOT Analysis of "Business Partners Prosperous" can be illustrated in table 1 below: Table 1. Village-Owned Enterprise SWOT Analysis "Prosperous Business Partners"

\begin{tabular}{|c|c|}
\hline Element & Description \\
\hline Strength & $\begin{array}{l}\text { concept of a comfortable garden for sitting and walking. It does not carry the currently } \\
\text { popular theme and is applied by other Village-Owned Enterprise that carry the iconic } \\
\text { spot selfie, which is a special characteristic for Village-Owned Enterprise "Taman } \\
\text { Usaha Makmur" lazuardi park. In addition to the concept of a comfortable park, } \\
\text { Village-Owned Enterprise "Taman Usaha Makmur" lazuardi park as well as an } \\
\text { educational vehicle for children to learn about plants, animals and other sports } \\
\text { conceptualized in a tour package, where children can play and learn archery there with } \\
\text { equipment that has been complete enough available. }\end{array}$ \\
\hline Weakness & $\begin{array}{l}\text { still lack of promotion done. Still limited to the distribution of brochures via online } \\
\text { and online, they have not been able to door to door because of the lack of Human } \\
\text { Resources (HR) in helping to promote Village-Owned Enterprise "Prosperous } \\
\text { Business Partners". In addition, access to a place to learn about cattle which is } \\
\text { separated from the lazuardi park is a bit of an obstacle because visitors are required to } \\
\text { walk out of the park. }\end{array}$ \\
\hline Opportunity & $\begin{array}{l}\text { in the future development Village-Owned Enterprise "Prosperous Business Partners" } \\
\text { Susukan Village Sumbang District has a great opportunity to develop tourism packages } \\
\text { that target kindergarten children with wider area coverage, assisted by more intensive } \\
\text { promotion. Then the opportunity for a food court across the Village-Owned Enterprise } \\
\text { road by accommodating sellers who sell around in front of Village-Owned Enterprise } \\
\text { becomes a neater and more attractive arrangement. With the available natural } \\
\text { resources, in Susukan Village, Village-Owned Enterprise can make Susukan Village } \\
\text { become a tourism village by providing packages for tour events, ranging from seeing } \\
\text { the potential of plants and animals in Susukan Village, learning to make salted eggs to } \\
\text { the home industry, learning to make sugar and etcetera. }\end{array}$ \\
\hline Treath & $\begin{array}{l}\text { development of trends in society today about Village-Owned Enterprise that utilize the } \\
\text { natural potential in their villages, giving rise to new competitors who make the concept } \\
\text { is almost the same as Village-Owned Enterprise "Mitra Usaha Makmur". This is } \\
\text { considered by the management itself not to be a significant threat, but rather to be a } \\
\text { race to continue to improve its performance, and will also be beneficial because it will } \\
\text { form a mindset by the outside community that in Sumbang District there are many } \\
\text { tourists, from Village-Owned Enterprise not only Susukan Village. }\end{array}$ \\
\hline
\end{tabular}

Source: Primary data processed

\section{Discussion and Conclusion}

Based on the findings obtained in the field, the roles of each commissioner, manager, supervisor, and Village- 
Owned Enterprise workforce "Mitra Usaha Makmur" is a concrete manifestation of the application of the organizational structure, in which there is a delegation of tasks and authority by the superiors to help the achievement of the purpose of the organization is Village-Owned Enterprise "Mitra Usaha Makmur". In accordance with the opinion of Hasibuan (2010), organizational structure is a picture depicting the type of organization, departmental organization position, and the type of official authority, field and job relations, line of command and responsibility, range of control and organizational leadership system. All parties work together to build Village-Owned Enterprise so that they are able to produce good performance to achieve a prestigious VillageOwned Enterprise. In Village-Owned Enterprise "Mitra Usaha Makmur" the chairman always provides motivation in the form of appreciation and direction to other members so that they can improve their performance. As stated by Srimindarti (2006), employee performance is not just information to be able to do salary promotion or determination for the company, but how the company can motivate employees and develop a plan to improve performance slump so that it can be avoided. The spirit of building villages becomes the basis of their work, so as to produce satisfactory performance for the surrounding community.

Village-Owned Enterprise SWOT analysis results "Mitra Usaha Makmur" produced provides new information for Village-Owned Enterprise, which internal and external factors are the concern of Village-Owned Enterprise in developing future strategies. Internal factors of Village-Owned Enterprise need to be planned strategies for developing human resources (HR) as managers so as to be able to grow a critical attitude towards change and innovation, expand capital for the development of new business units, and increase marketing strategies. Whereas the focus of the Village-Owned Enterprise external factor itself is how to deal with the emergence of new VillageOwned Enterprise competition. This can be pursued a strategy to strengthen the local wisdom of the implant village, so as to be able to maintain the characteristics of the Village-Owned Enterprise of the implant village itself with all its potential.

\section{References}

AA Anwar Prabu Mangkunegara. 2006. Human Resource Performance Evaluation. Jakarta: PT Refika Aditama

Ministry of National Education Center for Development System Dynamics Studies. (PKDSP). 2007. Handbook for the Establishment and Management of Business Entities

Social Service and Community and Village Empowerment. 2019. Category Village-Owned Enterprise Regency Banyumas

Dispermades Dukcapil Central Java. 2017. Developments of Village-Owned Enterprise in Central Java Province

Guyton AC, Hall JE. 1996. Textbook of Medical Physiology. Jakarta: EGC PO Medical Book Publisher (Translation from: Textbook of Medical Physiology)

Hasibuan. 2010. Human Resource Management. Jakarta: Bumi Aksara

Kotler and Keller. 2009. Marketing Management. Volume I. 13th Edition. Jakarta: Erlangga

Murdjianto.2001. Human Resource Management. Bandung : Bina Atmaja

Peraturan Village Government No. 4 of 2015

Srimindarti, Caecilia, 2006. The Balanced Scorecard As An Alternative To Measure Performance,Journal: economic focus

Sugiyono.2014. Qualitative Quantitative Research Methods and R\&D. Bandung

Sutrisno, Edi. 2009. Human Resource Management First edition. Jakarta: Kencana Prenada Media Group

Law No. 32 of 2004 concerning Regional Government 